\title{
Rhabdomyosarcoma of Reproductive Organs in Adult Females. Description of 5 Cases- Literature Review
}

\section{Barbara Kozakiewicz, Małgorzata Czetwertyńska, Małgorzata Chądzyńska and Marta Reczek}

Maria Skłodowska-Curie Memorial Cancer Center and Institute of Oncology, 02-781 Warsaw, Wilhelma Konrada Roentgena St.5, Poland

*Corresponding author: Barbara Kozakiewicz, Maria Skłodowska-Curie Memorial Cancer Center and Institute of Oncology, 02-781 Warsaw, Wilhelma Konrada Roentgena St.5, Poland, Tel:0048225462000; E-mail: wum@wp.eu

Received date: November 22, 2017; Accepted date: November 27, 2017; Published date: December 04, 2017

Copyright: (c) 2017 Kozakiewicz B, et al. This is an open-access article distributed under the terms of the Creative Commons Attribution License, which permits unrestricted use, distribution, and reproduction in any medium, provided the original author and source are credited.

\section{Abstract:}

Background: Rhabdomyosarcoma (RMS) is the most common soft tissue sarcomas. It was described for the first time by Weber in 1854. RMS is recognized in approx. $90 \%$ of patients fewer than 20 years of age. The disease in adults is extremely rare.

Materials and Methods: A retrospective analysis was performed on 5 cases of RMS of the female genital tract. These 5 cases of the disease in women aged 20 and 87 years of age treated in a Warsaw hospital from 1991 to 2013. In all women the diagnosis was made on the basis of histopathological examination of tissues after excision of changes in the vulva and vagina. Tumors were classified according to the Intergroup Rhabdomyosarcoma Study (IRS) staging. All patients were treated with multimodality treatment: surgery, chemotherapy and/or ratiotherapy.

Results: Of the five patients with RMS, three originated from the vagina one from vulvae and one from Bartholin's glands. Two out of 5 patients presented with distant metastasis and death after 9 and 4 years. Tree patients alive for 3,10, 11 years without recurrence or active disease a median duration was of 7.7 years.

Conclusion: RMS in adults have poor prognosis as compared to childhood RMS. Adult RMS should therefore be treated aggressively with multidisciplinary approach comprising of surgery, radiation, and chemotherapy to achieve cure and prolonged survival. The prognosis of embryonal rhabdomyosarcoma of female genital tract is good. The standard treatment for adults RMS consisting the multimodal therapy with radical surgery and chemotherapy and radiotherapy.

Keywords Rhabdomyosarcoma; Reproductive organs; Embryonal rhabdomyosarcoma; Soft tissue sarcoma

\section{Introduction}

One of the most common malignancies in children under the age of sixteen next the leukemia, tumors of the CNS (central nervous system), lymphomas and neuroblastoma are soft tissue sarcomas (STS), which constitute approx. $7 \%$ of all cancers diagnosed in minors. They originate from mesenchymal or neuroectodermal embryonic tissue [1]. In half the cases, they are localised in the extremities, in the peritoneal cavity in approx. $20 \%$ of patients, in the retroperitoneum (15\%) and appear in the vicinity of the head and neck (10\%) [2]. Among the histological types of soft tissue sarcoma, the most common among minors is rhabdomyosarcoma, diagnosed in $69 \%$ of sick children and synovial sarcoma, which accounts for $10 \%$ of patients [1]. The diagnosis of sarcoma in adults occurs sporadically, there are less than one thousands of these cases per year in Poland [3].

\section{Rhabdomyosarcoma}

Rhabdomyosarcoma (RMS) is the most common soft tissue sarcomas [1]. It was described by Weber in 1854. The most common location is the area of the head and neck, in $35-40 \%$ of cases, and the genitourinary system, limbs and torso. RMS is recognized in approx. $90 \%$ of patients aged less than 20 years. Cases of RMS occur in two age groups: 5-10 years of age and constitutes approx. $60-70 \%$ of all cases, and 10-19 years of age, and disease among adults is very rare [2-4]. Sarcomas are characterized by rapid invasive growth, high recurrences and multiple metastases [3]. The risk of disease is increased among patients with comorbidities such as the Li-Fraumeni syndrome, Gardner syndrome or Beckwith-Wiedemann syndrome [1,4].

On the basis of histological criteria WHO in 2013 types are distinguished, distinct in terms of clinical features and molecular biology: embryonal, spine cell-Sclerosing, alveolar and pleomorphic type. Variability in the incidence and prognosis of these types is presented in Table 1 [3-6].

The prognosis for recovery may be affected by the presence of anaplastic tissue in embryonal and alveolar tumours. According to a study developed by the American Institute of Pathology of the Armed Forces of the United States and Rabdomyosarcoma classification by Horn and Enterline WHO, 2013 among the diagnosed RMS of the embryonal type (60\%), botryoid (10\%), Spindle cell (3-6\%) and alveolar (solid) 25\%, pleomorphic (anaplastic) (5\%). Undifferentiated sarcomas are classified as a separate category, not part of RMS family $[3,6]$. Classification of clinical stages of soft tissue sarcoma is done in two ways, by assigning the disease to the appropriate groups based on age criterion: 1- IRSG system (Intergroup Rhabdomyosarcoma Study) used in children divides patients into four groups according to severity and treatment options. 2-TNM system used mainly in adults according 
Citation: Kozakiewicz B, Czetwertynska M, Chadzynska M, Reczek M (2017) Rhabdomyosarcoma of Reproductive Organs in Adult Females.

to the American Joint Committee on Cancer and the Union for International Cancer Control (AJCC\&UICC) (Table 2) [1].

\begin{tabular}{|c|c|c|c|c|}
\hline \multirow{3}{*}{ Feature } & \multicolumn{4}{|l|}{ Rhabdomyosarcoma } \\
\hline & \multicolumn{2}{|l|}{ Embryonal } & \multirow{2}{*}{$\begin{array}{l}\text { Alveolar ARMS } \\
\text { Anaplastic }\end{array}$} & \multirow{3}{*}{$\begin{array}{l}\text { Pleomorphic } \\
30-50 \text { years of age }\end{array}$} \\
\hline & Botryoides & Spindle cell & & \\
\hline \multirow{2}{*}{ Age } & \multicolumn{2}{|l|}{$<10$ years of age } & $0-19$ years of age & \\
\hline & Mainly children & Children and adults & Mainly adults & \\
\hline \multirow{2}{*}{ Incidence } & \multicolumn{2}{|l|}{ Approx. 60\% } & Approx. $20-25 \%$ & \multirow{2}{*}{$<5 \%$} \\
\hline & Approx. $6-10 \%$ & Approx. 3\% & & \\
\hline $\begin{array}{l}\text { Most common } \\
\text { location }\end{array}$ & $\begin{array}{l}\text { The vagina, bladder, and } \\
\text { nasopharynx (the nasopharynx } \\
\text { typically affects older children). }\end{array}$ & $\begin{array}{l}\text { Testis area is rare in the head and } \\
\text { neck. Former spindle cell or } \\
\text { leiomyomatous ERMS }\end{array}$ & $\begin{array}{l}\text { ARMS tend to form more often in } \\
\text { the extremities, trunk, and } \\
\text { peritoneum. }\end{array}$ & $\begin{array}{l}\text { Muscles of the Limbs } \\
\text { Torso }\end{array}$ \\
\hline $\begin{array}{l}\text { Cytogenetic } \\
\text { aberrations }\end{array}$ & $\mathrm{LOH}$ & MYOD1 mutations & Translocation FKHR, PAX3,7 & - \\
\hline Survival & $\sim 60-70 \%$ & $\sim 95 \%$ & $\sim 50 \%$ & $\sim 5 \%$ \\
\hline
\end{tabular}

Table 1: Comparative characteristics of the types of rhabdomyosarcoma [3-6].

\begin{tabular}{|c|c|c|c|c|c|}
\hline Stage & $\mathbf{T}$ & $\mathbf{N}$ & M & Histologic Grade & Estimated Survival \\
\hline \multirow{2}{*}{ Stage IA } & $\mathrm{T} 1 \mathrm{a}$ & No & MO & G1,GX & \multirow{4}{*}{ Approx. 90\% } \\
\hline & $\mathrm{T} 1 \mathrm{~b}$ & NO & MO & $\mathrm{G} 1, \mathrm{GX}$ & \\
\hline \multirow{2}{*}{ Stage IB } & $\mathrm{T} 2 \mathrm{a}$ & NO & MO & G1,GX & \\
\hline & $\mathrm{T} 2 \mathrm{~b}$ & NO & MO & G1,GX & \\
\hline \multirow{2}{*}{ Stage IIA } & $\mathrm{T} 1 \mathrm{a}$ & No & Mo & G2, G3 & \multirow{4}{*}{ Approx. $70 \%$} \\
\hline & $\mathrm{T} 1 \mathrm{~b}$ & NO & MO & G2, G3 & \\
\hline \multirow{2}{*}{ Stage IIB } & $\mathrm{T} 2 \mathrm{a}$ & No & MO & G2 & \\
\hline & $\mathrm{T} 2 \mathrm{~b}$ & No & MO & G2 & \\
\hline \multirow{2}{*}{ Stage III } & T2a, T2b & NO & MO & G3 & \multirow{2}{*}{ Approx. 50\% } \\
\hline & Any $T$ & N1 & MO & Any $G$ & \\
\hline Stage IV & Any $T$ & Any $\mathrm{N}$ & M1 & Any $G$ & $<15 \%$ \\
\hline
\end{tabular}

Table 2: Clinical stages of soft tissue sarcomas according to the AJCC/UICC system from 2015 [1,7].

Clinical symptoms of RMS depend on tumor size and location. Presence within the organ causes the disorder of its functions. On the basis of pain, swelling, blood circulation disorders, paresthesia or numbness in the examination of the patient, the fact of infiltration of surrounding tissues by tumor can be determined $[1,8]$. Despite the considerable diversity of different histological types, the clinical images of soft tissue sarcomas are similar to each other. A disturbing and suspicious symptom towards developing soft tissue sarcoma is a painless subfascial lump. Formation of a so-called "pseudo tumor", which is a reaction to the pressure, is a characteristic trait, which depends on the histological form interacting with a different intensity with the surrounding tissue [2]

Diagnosis should be based on interviews and physical examination, imaging, histopathological and laboratory tests. Histopathological results are necessary to make a definitive diagnosis. Immunohistochemical markers necessary to differentiate the various types of sarcomas are: - desmin, vimentin, myoglobin, keratin, protein S-100, NSE, actin, MIC-2. Molecular studies are useful only in certain soft tissue sarcomas, eg. In alveolar (RMS RMA) rhabdomyosarcoma has distinct molecular characteristics. A unique translocation occurs 
between the FKHR gene on chromosome 13 and either the $P A X 3$ gene on chromosome $2(70 \%)$ or the $P A X 7$ gene on chromosome $1(30 \%)$. Individuals with the $P A X 7$ translocation are younger and may have longer event-free survival than those with the $P A X 3$ translocation. Unlike embryonal rhabdomyosarcoma, alveolar rhabdomyosarcoma commonly demonstrates gene amplification, and its DNA content is typically tetraploidy $[9,10]$.

The best results are achieved after radical surgical resection of primary tumour in the total extent (R0). In case of leaving cancerous tissue in the microscopic scale ( $\mathrm{R} 1$ resection) reoperation is recommended, if radical removal of the lesion is possible. Depending on the five parameters: original location, tumour size, histopathological diagnosis, age and the type of resection, patients after surgical resection R1 (microscopic leaving of sarcoma tissue) and R2 (macroscopic leaving of tissues) and after initial chemotherapy are directed to further radiotherapy treatment [1,2]. Conformal radiotherapy associated with surgical removal of the primary lesion and possible metastases is currently one of the standard treatments for soft tissue sarcomas. The use of the combination of radical surgery (R0) with complementary radiotherapy combined with many weeks of rehabilitation allows for achieving 5-year survival in $85-90 \%$ of patients [2]. The purpose of the paper is to present a diagnosis method, the course of disease and treatment of embryonal rhabdomyosarcoma among women aged from 20 to 87 years the median age was 34 years, based on own experience of these rarely diagnosed cancers. In the period from 1991 to 2013, were treated 5 women with diagnosed RMS in the area of the vagina (3), vulvae (1) and the Bartholin's gland at the Oncology Centre in Warsaw. In all women, the diagnosis was made on the basis of histopathological examination of tissues after excision of changes in the vulva and vagina. Diagnosis, course of the disease, treatment and its outcome in patients are presented in Table 3.

\begin{tabular}{|c|c|c|c|c|c|c|}
\hline $\begin{array}{l}\text { Patient } \\
\text { Year of } \\
\text { treatment }\end{array}$ & $\begin{array}{l}\text { Age of the } \\
\text { patient and } \\
\text { Period of } \\
\text { observation } \\
\text { changes in } \\
\text { months }\end{array}$ & $\begin{array}{l}\text { Primary tumour: } \\
\text { Results of gynaecological tests }\end{array}$ & $\begin{array}{l}\text { Microscopic } \\
\text { diagnosis } \\
\text { RMS } \\
\text { TYPE/G }\end{array}$ & 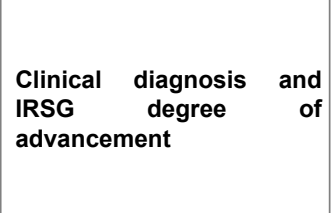 & $\begin{array}{l}\text { Primary } \\
\text { Supplementa } \\
\text { ry treatment } \\
\text { Treatment of } \\
\text { recurrences* }^{*}\end{array}$ & Outcome \\
\hline $\begin{array}{l}\text { 1. EB } \\
1991 \\
{[12]}\end{array}$ & $\begin{array}{l}20 \text { years } 6 \\
\text { months }\end{array}$ & $\begin{array}{l}\text { BG } \\
\text { Irregular tumour } 15 \times 8 \mathrm{~cm} \text { infiltration with an ulcer } \\
\text { penetrating to the bone }\end{array}$ & $\begin{array}{l}\text { EMBRIONAL } \\
\text { E } \\
\text { G3 }\end{array}$ & $\begin{array}{l}\text { Sarcoma of the Bartholin's } \\
\text { gland group III according to } \\
\text { IRS }\end{array}$ & $\begin{array}{l}\text { EX } \\
\text { CHTH+RV } \\
\text { BGND +RT38 } \\
\text { Gy } \\
\text { Rec } \quad 1999 \\
\text { CHTH }^{*},\end{array}$ & $\begin{array}{l}\text { Death after } 9 \text { years } \\
\text { metastases to the } \\
\text { lungs }\end{array}$ \\
\hline $\begin{array}{l}\text { 2. HB } \\
1992\end{array}$ & $\begin{array}{l}33 \text { years } 3 \\
\text { months }\end{array}$ & $\begin{array}{l}\text { VA } \\
\text { Bulging lump } \\
\text { tumour } 3 \times 3 \mathrm{~cm} \text { reaching along the cervix all the } \\
\text { way to the external os. without ulceration }\end{array}$ & $\begin{array}{l}\text { BOTYROIDE } \\
\text { S } \\
\text { G1 }\end{array}$ & $\begin{array}{l}\text { Soft tissue sarcoma of the } \\
\text { vagina, group II A according } \\
\text { to IRS }\end{array}$ & $\begin{array}{l}\text { EX } \\
\text { RT60Gy+RV + } \\
\text { BGND } \\
\text { Lobectomia } \\
\text { EX R0-a 1993; } \\
\text { EX, RT- cost } \\
\text { a } 1995\end{array}$ & $\begin{array}{l}\text { Death after } 4 \text { years } \\
\text { metastases to the } \\
\text { lungs }\end{array}$ \\
\hline $\begin{array}{l}\text { 3. SH } \\
2000\end{array}$ & $\begin{array}{l}43 \text { years } 3 \\
\text { months }\end{array}$ & $\begin{array}{l}\text { VA } \\
\text { Irregular body measuring tumour } 3 \times 4 \mathrm{~cm} \\
\text { reaching along the cervix all the way to half the } \\
\text { length of the vagina }\end{array}$ & $\begin{array}{l}\text { EMBRIONAL } \\
\text { E } \\
\text { G2 }\end{array}$ & $\begin{array}{l}\text { Soft tissue sarcoma of the } \\
\text { vagina, group II B according } \\
\text { to IRS }\end{array}$ & $\begin{array}{l}E X \\
R V+B G D N\end{array}$ & $\begin{array}{l}\text { Alive for } 10 \text { years } \\
\text { without recurrence }\end{array}$ \\
\hline $\begin{array}{l}\text { 4. KW } \\
2013\end{array}$ & $\begin{array}{l}87 \text { years } 2 \\
\text { months }\end{array}$ & $\begin{array}{l}\text { VA } \\
\text { Tumour } 10 \times 7 \mathrm{~cm} \\
\text { ulcerated }\end{array}$ & $\begin{array}{l}\text { BOTRYOIDE } \\
\text { S } \\
\text { G3 }\end{array}$ & $\begin{array}{l}\text { Soft tissue sarcoma of the } \\
\text { vagina, group III according } \\
\text { to IRS }\end{array}$ & $\mathrm{EX}+\mathrm{CHTH}$ & $\begin{array}{lll}\text { Alive for } & 3 & \text { years } \\
\text { without } & \text { active } \\
\text { disease } & \end{array}$ \\
\hline $\begin{array}{l}\text { 5. } \mathrm{NN}^{*} \\
2006 \\
2012^{*}\end{array}$ & $\begin{array}{l}23 \text { years } 8 \\
\text { months } \\
{ }^{*} 29\end{array}$ & $\begin{array}{l}\text { VU } \\
\text { Tumour } 2 \times 4 \text { cm ulcerated } \\
{ }^{*} \text { Ca ani (ca squamosa) }\end{array}$ & $\begin{array}{l}\text { BOTRYOIDE } \\
\text { S } \\
\text { G2 }\end{array}$ & $\begin{array}{l}\text { Sarcoma of the vulva, group } \\
\text { III according to IRS }\end{array}$ & $\mathrm{RV}+\mathrm{CHTH}$ & $\begin{array}{l}\text { Alive for } \\
11 \quad \text { year without } \\
\text { recurrence }\end{array}$ \\
\hline
\end{tabular}

BG-Bartholin's Gland; VA-Vagina; VU-Vulvae; RMS-Rhabdomysarcoma; EX-local excision; RV-Radical resection of the Vulva; BGND-Bilateral resection of lymph nodes; CHTH-Chemotherapy according to the CYVADIC programme; RT-Radiotherapy; * 6 yr later post RMS therapy diagnosis - ca ani - treated surgery/ RT/CHTH

Table 3: Characteristics of women treated for gynaecological sarcoma in 1991-2013 in Warsaw.

All of 5 patients initially received surgery, and 3 received just chemotherapy regimen of CYVADIC for 12 cycles. After receiving surgery and the postoperative adjuvant chemotherapy, the patient has maintained tumor-free from $8,5,3$ years so far. Two patients had metastases to the lungs and one of them has recurrence 8 years after the surgery. The second patient has metastasis in VII and IX cost 1 and 3 years after surgery. This two patient's death after 9 and 4 years with metastases to the lungs. The follow-up was from 3 to 11 years, with a 
median duration of 7.7 years (range 36 132 months). Five patients were identified, two were already dead 9 and 4 years, and the remaining 3 were followed up without recurrence.

\section{Discussion}

Gynaecological sarcomas are a rare cancer in adult women. Among these cancers, rhabdomyosarcoma is the most frequently diagnosed. Its subtypes botryoides and embryonal account for about $10 \%$ of all RMS. [11-15].

RMS mainly affects children and better survival results are observed in this group than in the adult group (65\% vs $55 \% \mathrm{p}<0.0001)$ [16]. These differences in adult recovery are explained by late diagnosis in this age group and wrong treatment [17]. Some authors in order to improve treatment results suggested even pelvic exenteration as the best treatment for vaginal RMS [18]. An opinion currently dominates, supported by the survival results achieved, that the wide excision of the tumour R0 and no metastases in the lymph nodes is a positive prognostic factor. In the described cases of the incidence of RMS, the patients without metastases to lymph nodes lived for many years without recurrence of the disease and metastasis present in lymph nodes is combined with treatment failure.

This paper presents 5 cases of embryonal rhabdomyosarcoma of the reproductive organs in adult women. It astonishes that in all the presented cases, at the moment of diagnosis of tumours surrounding the vagina or vulva reached a diameter of $3-15 \mathrm{~cm}$ in the course of observation lasting from a few weeks to 8 months. During this period, all patients had other non-cancerous diseases diagnosed and were repeatedly treated or punched before placing a definitive diagnosis. The age of patients at diagnosis of embryonal RSM ranged from 20, 50, 52 to 87. MRI and PET were used to illustrate the range of changes in the pelvis in patients treated in the US, Korea and Tunisia. Only in our country the tests were limited to ultrasound [11-14]. Treatment in all patients consisted of surgical excision of the primary tumour.

Rhabdomyosarcomas may arise as low-differentiated tumours with the characteristics of germ cell tumours of muscle origin characterised by significant dynamics of invasion. Sarcomas diagnosed in young women may also occur in pregnant women $[19,20]$. But they are always characterised by rapid growth and during the initial growth are classified as benign. Rapid growth and achievement of a large size (over $5 \mathrm{~cm}$ in diameter) and ulceration of the skin, appearance of metastasis to inguinal, femoral and pelvic lymph nodes indicates the cancerous nature of the disease. The different types of sarcomas are slightly different in terms of incidence and not different in their clinical course. Sarcoma observed in patients infiltrated surrounding tissues in a short time but ulcers were not found from the beginning of the disease. In patients with disease localised in the Bartholin gland and its surroundings, numerous diagnostic punctures were often performed, as an abscess was diagnosed and not a tumour. Pain in all patients appeared late, only when a large area of adjacent tissue was covered by the disease. Tumour size at diagnosis in patients with sarcomas is an important prognostic factor. Some authors have observed that the diameter of the infiltration above $5 \mathrm{~cm}$ correlates with a worse outcome and often metastases occurring in these patients [21].

The most important factors in prognosis are the disease stage at diagnosis and the area of infiltrated tissues [22,23]. Although the molecular factors are examined for different types of RMS, the clinical features of the sarcoma are the most important in assessing the prognosis: The depth of muscle invasion, a single tumour growth in the absence of lymph node metastasis and histological subtype embryonal. In the coexistence of these features, we can expect less disease dynamics and use less invasive treatment $[21,22]$. Still radical surgery (R0) is the primary treatment for RMS, although chemotherapy is increasingly used, its impact is being discussed. With the discovery of unfavourable prognostic features, both chemotherapy and radiotherapy are recommended [2,21-23].

All the previously described types of sarcomas require radical surgical excision of the vulva and in patients with altered lymph nodes also linked with their removal. Radical surgical treatment (R0) performed has higher survival rates in patients treated this way. Radiotherapy is recommended after surgical treatment, and chemotherapy in the case of spread to distant organs [2,12-14].

Leiomyosarcoma type of Sarcomas can occur in pregnancy and steroid receptors for oestrogen (ERC) and progesterone (PRC) can occur in the sarcoma tissue, hence it is speculated that perhaps the etiology of this tumour is associated with the use of hormones and hormone therapy could be tried in the treatment of this tumour $[24,25]$.

Chemotherapy for the treatment of soft tissue sarcomas has been used since 1960 as preoperative treatment. According to Gordon's report, 6 to 12 course should be carried out according to the CYDAVIC programme. It is now also used in the case of the spread or recurrence of the disease [26]. The results of this treatment are unsatisfactory.

The probability of curing adult patients is not high, five-year eventfree survival (ESF) is in the range: $30-40 \%$. In the case of embryonal RMS, survival is reached in only about $10 \%$ [6]. Recurrences are observed in $77 \%$ and distant metastases in $55 \%$ of patients [21,27].

So far there is no unified treatment protocol for patients with RMS, which is associated with rare illnesses among adult women. Some authors suggest that poor prognosis as to curing these patients is associated with synchronous illnesses to other cancers, and therefore recommend, e.g. in patients with diagnosed RMS in reproductive organs, removal of the appendix, which is a place of coexistence of the carcinoid [28].

Assessing the group of patients described, the prognosis for survival can be improved if the disease is diagnosed early, before there is extensive infiltration of the tissues surrounding the tumour and when there is be no spread to lymph nodes. RMS in adults have poor prognosis as compared to childhood RMS. Adult RMS should therefore be treated aggressively with multidisciplinary approach comprising of surgery, radiation, and chemotherapy to achieve cure and prolonged survival. But prognosis of embryonic rhabdomyosarcoma of female genital tract is good [29]. The standard treatment for these women RMS consisting the multimodal therapy with radical surgery and chemotherapy and radiotherapy. These observations, however, require further research on numerically larger groups of patients.

\section{Conclusion}

RMS in adults have poor prognosis as compared to childhood RMS. Adult RMS should therefore be treated aggressively with multidisciplinary approach comprising of surgery, radiation, and chemotherapy to achieve cure and prolonged survival. The prognosis of embryonal rhabdomyosarcoma of female genital tract is good. The 
Citation: Kozakiewicz B, Czetwertynska M, Chadzynska M, Reczek M (2017) Rhabdomyosarcoma of Reproductive Organs in Adult Females. Description of 5 Cases- Literature Review. J Oncol Med \& Pract 2: 114.

Page 5 of 5

standard treatment for adults RMS consisting the multimodal therapy with radical surgery and chemotherapy and radiotherapy.

\section{References}

1. Krzakowski M, Warzocha K. et al. (2013) Soft tissue sarcoma in adults Recommendations for diagnostic and therapeutic procedures in malignant tumors.

2. Ruka W, Rutkowski P, Krzakowski M, Grzesiakowska U, Ptaszyński K, et al. (2010) Soft tissue in adults \& ndash; Principles of diagnostic and therapeutic procedures. Nowotwory J Oncol 60: 55-65.

3. Tarnowski M, Grymuła K, Tkacz M, Czerewaty M, Poniewierska-Baran A, et al. (2014) Molecular mechanisms regulating metastasis of cancer cells with special emphasis on rhabdomyosarcoma. Progress Hig Med Exp 68: 258-270.

4. Guy JB, Casteillo F, Vallard A, Espenel S, Forest F, et al. (2016) Rhabdomyosarcoma of adult genital tract: A short review. J Gynecol Obstet Biol Reprod (Paris) 45: 821-826.

5. Meza JL, Anderson J, Pappo AS, Meyer WH, Children's Oncology Group (2006) Analysis of prognostic factors in patients with nonmetastatic rhabdomyosarcoma treated on intergroup rhabdomyosarcoma studies III and IV: The children's oncology group". J Clin Oncol 24: 3844-3851.

6. Allagio R, Coffin CM (2015) The evolution of pediatric soft tissue sarcomas classification in the last 50 years. Pediatr Dev Pathol 18: 481-494.

7. Gounder MM, Carvajal RD (2015) Soft tissue sarcoma staging. Medscape 2006584.

8. Kazanowska B, Chybicka A (2015) Tumors of soft tissues. Sarcomas 868-893.

9. Duan F, Smith LM, Gustafson DM, Zhang C, Dunlevy MJ, et al (2012) Genomic and clinical analysis of fusion gene amplification in rhabdomyosarcoma: A report from the Children's Oncology Group. Genes Chromosomes Cancer 51: 662-674.

10. Missiaglia E, Williamson D, Chisholm J, Wirapati P, Pierron G, et al. (2012) PAX3/FOXO1 Fusion gene status is the key prognostic molecular marker in rhabdomyosarcoma and significantly improves current risk stratification. J Clin Oncol 30: 1670-1677.

11. Kozakiewicz B, Dmoch-Gajzlerska E, Roszkowska-Purska K (2014) Carcinomas and sarcomas of the Bartholin gland. A report of nine cases and review of the literature. Eur J Gynaecol Oncol 35: 243-249.

12. Shim AR, Lee M, Paek J, Kim MJ, Kim SW (2011) A case of embryonal rhabdomyosarcoma of the uterine cervix in a middle-aged women. Korean J Obstet Gynecol 54: 707-711.

13. Garrett LA, Harmon DC, Schorge JO (2013) Embryonal rhabdomyosarcoma of the uterine corpus. J Clin Oncol 31: 48-50.

14. Abdeljalil K, Asma B, Kouira M, Faten H, Sawssen M, et al. (2014) Embryonal Rhabdomyosarcoma of the uterine cervix: Two cases report and literature review. Open J Obstet Gynecol 4: 868-873.
15. Dehner LP, Jarzembowski JA, Hill DA (2012) Embryonal Rhabdomyosarcoma of the uterine cervix: A report of 14 cases and a discussion of its unusual clinicopathological associations. Mod Pathol 25: 602-614.

16. Sultan I, Qaddoumi I, Yaser S, Rodriguez-Galindo C, Ferrari A (2009) Comparing adult and pediatric rhabdomyosarcoma in the surveillance, epidemiology and end results program, 1973 to 2005: An analysis of 2600 patients. J Clinic Oncol 27: 3391-3397.

17. Baiocchi G, Faloppa CC, Osório CA, Kumagai LY, Fukazawa EM, et al. Embryonal rhabdomyosarcoma of the uterine cervix in a 47-year-old woman. J Obstet Gynaecol Res 37: 940-946.

18. Hilgers RD, Malkasian GD Jr, Soule EH (1970) Embryonal rhabdomyosarcoma (botryoid type) of the vagina: A clinicopathologic review. Am J Obstet Gynecol 107: 484-502.

19. Ulbright TM, Brokaw SA, Stehman FB, Roth LM (1983) Epithelioid sarcoma of vulva. Evidence suggesting a more aggressive behavior than extra-genital epithelioid sarcoma. Cancer 52: 1462-1469.

20. Konefka T, Senkus E, Emerich J, Dudziak M (1994) Epithelioid sarcoma of the Bartholin's gland primarily diagnosed as vulvar carcinoma. Gynecol Oncol, 66: 188-189.

21. Fong Y, Coit DG, Woodruff JM, Brennan MF (1993) Lymph node metstasis from soft tissue sarcoma in adults. Analysis of data from prospective datebase 1772 sarcoma patients. Ann Surg 217: 72-77.

22. Khosla D, Gupta R, Srinivasan R, Patel FD, Rajwanshi A (2012) Sarcomas of uterine cervix: Clinicopathological features, treatment and outcome. Int J Gynecol Cancer 22: 1026-1030.

23. Crist W, Gehan EA, Ragab AH, Dickman PS, Donaldson SS, et al. (1995) The third intergroup rhabdomyosarcoma study. J Clinic Oncol 13: 610-630.

24. Nielsen GP, Rosenberg AE, Koerner FC, Young RH, Scully RE (1996) Smooth-muscle tumors of vulva. A clinicopathplogical study 25 cases of review of the literature. Am J Surg Pathol 20: 779-793.

25. Tavassoli FA, Norris HJ (1979) Smooth muscle tumors of vulva. Obstet Gynecol 53: 213-217.

26. Gordon AN, Montag TW (1990) Sarcoma botryoides of the cervix: Excision followed by adjuvant chemotherapy for preservation of reproductive function. Gynecol Oncol 36: 119-124.

27. Khosla D, Sapkota S, Kapoor R, Kumar R, Sharma SC (2015) Adult rhabdomyosarcoma: Clinical presentation, treatment, and outcome. J Cancer Res Ther 11: 830-834.

28. Adams BN, Brandt JS, Loukeris K, Holcomb K (2011) Embryonal rhabdomyosarcoma of the cervix and appendiceal carcinoid tumor. Obstet \& Gynecol 117: 482-484.

29. Yuan G, Yao H, Li X, Li H, Wu L (2017) Stage 1 embryonal rhabdomyosarcoma of the female genital tract: A retrospective clinical study of nine cases. World J Surg Oncol, 15: 42. 